\title{
COPING WITH MINES A Critical Risk For Repatriating Kurds
}

\author{
John R. Rogge
}

The risk to civilians from mines and unexploded munitions is a problem common to most areas subject to prolonged warfare and insurgencies. Afghanistan has been attempting to deal with the problem for some time, while countries like Angola, Cambodia, Ethiopia and Mozambique will certainly need to address the issue in the near future. So must Iraq. Not only are the immediate border areas with Iran, Syria and Turkey heavily mined, but mines have been sown throughout much of Iraqi Kurdistan over the past two decades. Many of these mines are in areas currently being repopulated and the death toll and maiming of civilians caused by mines and other unexploded ordinance is a critical problem throughout much of the region. While some limited mine clearance was undertaken by the U.S. military in the immediate vicinity of Dohukand Zakho, mine-clearance activities by the allies was suspended with their withdrawal from Iraq in late summer of 1991 and there are no other agencies currently addressing the issue.

There are basically three groups of areas where mines are widespread. The first is along the border and especially in those regions along the Iran-Iraq border where extensive fighting took place during the eight year war and where territorial advantage shifted frequently. Both sides laid extensive mine fields, often well into Iraqi territory. It is doubtful whether the Iranians made maps of the fields they sowed, or, if they did, whether such maps would ever be released to a prospective mine-clearing

\footnotetext{
John Rogge is the Coordinator of the Disaster Research Unit at the University of Manitoba and recently undertook an assessment of reconstruction and rehabilitation needs for returning Kurdish refugees and other displaced persons in Iragi Kurdistan for the United Nations Development Program.
}

agency. Likewise, the Iraqi military maintains that while maps were made, these were kept locally and were destroyed during the recent Kurdish uprising (the same position is maintained by Iraqi government authorities with regard to the other two groups of minefields described below). Areas falling into this category include the region around Choman and the upper reaches of the Hamilton Road leading to the Haj Omer border point, the areas around Panjwin and especially throughout the pedicle that extends into Iran and the areas from Halabsha to the border.

Second, are areas surrounding military installations, especially in remote regions and including the many strategic mountain-top observation positions. The density of Iraqi military installations is one of the features of Iraqi Kurdistan that astounds most first-time visitors; there can be few areas in the world so heavily militarized as this region. These mines were laid for defensive reasons and the locations of such fields are usually known to local people. No clearing, however, has been begun in any of these areas. Since many are on steep mountain sides, there is the attendant risk of mines being washed down the mountain sides by either snow-melt or soil-creep.

A third group of mine fields are the most problematic; these may be referred to as opportunistic mine-fields. They were sown specifically to terrorize the Kurdish population. Their locations vary, but are widespread throughout the former so-called free-fire zones where all civilian movements were prohibited. Sites of such mines include the verges along roads, in orchards and in vineyards, around springs and wells and along mule tracks. The purpose of such mines was to discourage people from inhabiting the regions or attempting to return to their original villages. The extent of such minefields remains a matter of conjecture; their incidence is perhaps somewhat less than that proposed by Kurdish militants but nevertheless, the frequent accidents they produce suggests that they are anything but uncommon and must, therefore, be dealt with if people are to safely return to their villages and farms.

Aside from the widespread distribution of mines, the problem is further complicated by the deployment of a great diversity of mines. One reliable source suggested that at least fourteen different types of mines have been deployed. They fall into two basic groups, namely, anti-personnel mines which deliver only an explosion and more often maim than kill and shrapnelloaded mines which are much more deadly. The latter are often wired together to explode in clusters. While not the most deadly, the small plastic coated mines (mostly of Italian origin) are of special concern because they are impossible to detect with standard mineclearing devices and their small size makes them difficult to spot. Moreover, some mines are set to detonate only at pressures exerted by humans; thus sheep and goats grazing an area without incident does not necessarily mean that mines are absent. The longevity of most mines, especially the plastictype, is more or less indefinite and thus this is not a problem that will diminish in severity over time.

The incidence of mine deaths and injuries is very high, particularly in areas falling into the first group above. For example, it was suggested by one otherwise reliable informant that in the fifteen-kilometer stretch along Hamilton Road between Choman and the Iranian border, at least 500 mine-related deaths had occurred in April and May this year and a much larger number had been 
maimed. Such a figure may be somewhat inflated; doctors with a small German NGO in Choman were unable to confirm the statistic. However, they were able to confirm that in the month following their arrival in Choman, there had been between three to five mine injuries per day, of which about half were fatal. At the time of my visit to their hospital there were five cases in their surgical ward, all of which had required amputations and three of which were children. Some fifty mine amputees were known to be residing in Choman in late June.

At the hospital at Diyana (Saddam Hospital), to which most cases in the

\section{"Consequently, it is incumbent upon the $U N$ system to initiate, as soon as possible and in conjunction with other appropriate agencies, a major mine- awareness and mine- clearance program throughout Iraqi Kurdistan."}

region were referred, mine injuries were the major cause of surgical procedures. About a dozen cases, again half of which were children, were resident at the hospital at the time of my visit. While no specific statistics on mine injuries had been kept by the hospital, the senior surgeon suggested that there had been between 800 to 1,000 mine and ordinance injuries in the Diyana basin during May and June, of which about twenty percent had been fatal. Records of mine injuries were kept at the Panjwin hospital another high risk area - where, during the period 1 April to 6 June 1991, a total of 262 ordinance-related injuries and 160 mine-related injuries had occurred, of which seventy were fatal.

Persons most at risk from mines and other unexploded ordinance are those collecting firewood - which, as spontaneous settlements grow, means that people must venture further into the hills to find supplies; persons getting clean water from mountain springs; peoplescavenging forbuildingmaterials or other items of value among abandoned Iraqi army outposts; and shepherds. It is clear that children perform many of these tasks and are, therefore, especially at risk from mines. Aside from human casualties, there is also a high loss of livestock; shepherds will only walk behind their herds because of a fear of mines.

If, therefore, there is to be any extensive resettlement and a resumption of traditional agricultural pursuits by Kurds in the valleys from which they have been systematically displaced over the past decade, then there is an urgent need to develop both a mine-awareness campaign and a comprehensive mineclearance operation. Whether the latter can or will ever be undertaken by the Iraqi military within the framework of a negotiated autonomy agreement between the government and the Kurdish Front clearly remains a matter of conjecture. Even if the will were there at some time in the future, there is some question about whether the Iraqi military has the necessary skills or capacity to mount an extensive campaign. High-level U.S. military respondents suggested that the Iraqi military's experience is limited to minesowing and it would be ineffective in any clearing operation. As for the Peshmerga (Kurdish Front guerrillas), their skills and experience with mine clearing is essentially limited to a few deserters from the Iraqi army.

The risks to returning Kurds from mines and other unexploded ordinance will, therefore, remain high throughout much of the region for many years unless a concerted effort is made to generate more awareness of the hazard and, in areas close to current habitation, to undertake a systematic mine-clearance program. Consequently, it is incumbent upon the UN system to initiate, as soon as possible and in conjunction with other appropriate agencies, a major mineawareness and mine-clearance program throughout Iraqi Kurdistan. Such a program should possibly be modelled on the program recently implemented in Afghanistan and the one designed and ready for implementation in Cambodia. Indeed, a Kurdish program has the advantage of drawing on the experiences garnered in Afghanistan. Moreover, while there appears to belittle expertise or equipment in Iraqi Kurdistan to undertake a major mineclearance program and hence technical assistance for such a task will need to be provided by outside agencies, the capacity in terms of human resources to provide a comprehensive mineawareness program in high-risk areas can readily be putin place by the Kurdish Front, providing some basic training and the appropriate literature is made available. Moreover, with adequate technical assistance, small village-based mine-clearance teams could also be trained and equipped.

\section{YORK LANES PRESS}

\section{RECENT PUBLICATIONS}

Refuge or Asylum: A Cholce for Canada. Edited by Howard Adelman and C. Micheel Lanphier

(1991)

$\$ 18.95$

Refugee Policy: Canada and the United States. Edited by Howard Adelman (1991)

Soviet.Jewish Emigration and Resettlement in the 19908. Edited by Tanya Basok and Robert J. Brym (1991)

Plus shipping and handling charges, and GST (where applicable).

Please send your order requests to:

York Lanes Press

Suite 351, York Lanes York University 4700 Keele Street, North York, Ontario, Canada N3J ip3

Tel: (416) 736-5843 Fax: (416) 736-5837 